This article was downloaded by:

On: 12 January 2009

Access details: Access Details: Free Access

Publisher Taylor \& Francis

Informa Ltd Registered in England and Wales Registered Number: 1072954 Registered office: Mortimer House, 37-41 Mortimer Street, London W1T 3JH, UK

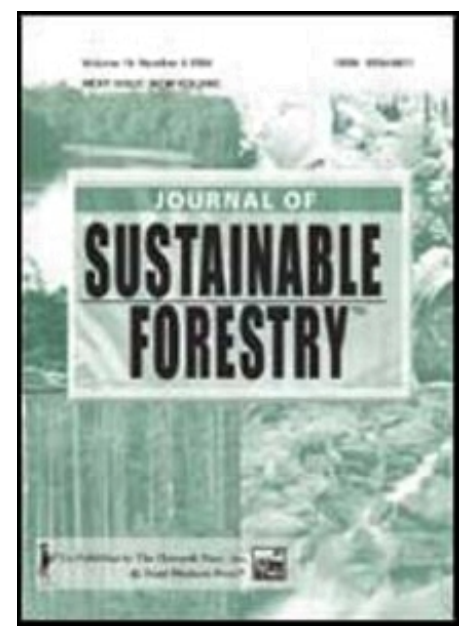

Journal of Sustainable Forestry

Publication details, including instructions for authors and subscription information:

http://www.informaworld.com/smpp/title content=t792306917

\title{
Effects of the Sustainable Forestry Initiative on the Quality, Abundance, and
} Configuration of Wildlife Habitats

João C. Azevedo ab; X. Ben Wu c; Michael G. Messina d; Richard F. Fisher ${ }^{e}$

a Departamento Florestal, Instituto Politécnico de Bragança, Bragana, Portugal b CIMO-Centro de Investigação de Montanha, Escola Superior Agrária, Instituto Politécnico de Bragança, Bragana, Portugal ${ }^{\circ}$ Department of Rangeland Ecology \& Management, Texas A\&M University, College Station, TX, USA d Department of Forest Science, Texas A\&M University, College Station, TX, USA ${ }^{e}$ Applied Research \& Development, Temple-Inland, Diboll, TX, USA

Online Publication Date: 19 October 2006

To cite this Article Azevedo, João C., Wu, X. Ben, Messina, Michael G. and Fisher, Richard F.(2006)'Effects of the Sustainable Forestry Initiative on the Quality, Abundance, and Configuration of Wildlife Habitats',Journal of Sustainable Forestry,23:1,37 — 65 To link to this Article: DOI: 10.1300/J091v23n01_03

URL: http://dx.doi.org/10.1300/J091v23n01_03

\section{PLEASE SCROLL DOWN FOR ARTICLE}

\footnotetext{
Full terms and conditions of use: http://www.informaworld.com/terms-and-conditions-of-access.pdf

This article may be used for research, teaching and private study purposes. Any substantial or systematic reproduction, re-distribution, re-selling, loan or sub-licensing, systematic supply or distribution in any form to anyone is expressly forbidden.

The publisher does not give any warranty express or implied or make any representation that the contents will be complete or accurate or up to date. The accuracy of any instructions, formulae and drug doses should be independently verified with primary sources. The publisher shall not be liable for any loss, actions, claims, proceedings, demand or costs or damages whatsoever or howsoever caused arising directly or indirectly in connection with or arising out of the use of this material.
} 


\title{
Effects of the Sustainable Forestry Initiative on the Quality, Abundance, and Configuration of Wildlife Habitats
}

\author{
João C. Azevedo \\ $\mathrm{X}$. Ben $\mathrm{Wu}$ \\ Michael G. Messina \\ Richard F. Fisher
}

\begin{abstract}
We analyzed the effects of landscape measures within the Sustainable Forestry Initiative (SFI) program on the suitability, abundance and spatial pattern of vertebrate habitats based on modeling and simulation of landscape and stand structure in a forested watershed in East Texas. Eight vertebrate species representing guilds established according to breeding and foraging requirements were selected: American beaver (Castor canadensis), American woodcock (Scolopax minor), pine warbler (Dendroica pinus), downy woodpecker (Picoides pubescens), barred owl (Strix varia), wild turkey (Meleagris gallopavo silvestris),
\end{abstract}

João C. Azevedo is Professor, Departamento Florestal, and Researcher, CIMOCentro de Investigação de Montanha, Escola Superior Agrária, Instituto Politécnico de Bragança, Campus de Santa Apolónia-Apartado 172, 5301-854 Bragança, Portugal (E-mail: jazevedo@ipb.pt).

$\mathrm{X}$. Ben Wu is Professor, Department of Rangeland Ecology \& Management, Texas A\&M University, College Station, TX 77843-2126 USA (E-mail: xbw@ tamu.edu).

Michael G. Messina is Professor, Department of Forest Science, Texas A\&M University, College Station, TX 77843-2135 USA (E-mail: m-messina@tamu.edu).

Richard F. Fisher is Operations Leader, Applied Research \& Development, Temple-Inland, P.O. Drawer N or 303 South Temple Drive, Diboll, TX 75941 USA (E-mail: DickFisher@templeinland.com).

The authors thank Instituto Politécnico de Bragança, Luso-American Development Foundation (FLAD), PRODEP III program, Portuguese government, and Temple-Inland Forest Products Corporation, Diboll.

Journal of Sustainable Forestry, Vol. 23(1) 2006

Available online at http://jsf.haworthpress.com

(C) 2006 by The Haworth Press, Inc. All rights reserved. doi:10.1300/J091v23n01_03 
fox squirrel (Sciurus niger) and gray squirrel (Sciurus carolinensis). Habitat suitability of the landscape in general increased with the implementation of SFI measures and habitat conditions were more diverse and even. Fragmentation and establishment of narrow and elongated habitat areas in a network configuration were the main consequences of the implementation of SFI measures in terms of habitat spatial structure. These changes were usually not limiting for the species analyzed. Mature pine and hardwood stands were absent from the simulated landscapes limiting the habitat for species like downy woodpecker or barred owl. Most of the species considered in this work benefited particularly from the implementation of streamside management zones (SMZs). doi:10.1300/ J091v23n01_03 [Article copies available for a fee from The Haworth Document Delivery Service: 1-800-HAWORTH. E-mail address: <docdelivery@haworthpress. com> Website: <http://www.HaworthPress.com> () 2006 by The Haworth Press, Inc. All rights reserved.]

KEYWORDS. Wildlife habitat quality and configuration, landscape, sustainable forestry, Sustainable Forestry Initiative (SFI), East Texas

\section{INTRODUCTION}

Biodiversity conservation requires a combination of measures at several scales. Traditionally it has relied on few, small, and isolated reserves. However, the majority of rare and endangered species exist outside reserves and there is lack of representation of species and ecosystems in the existing reserves (Soulé and Terborgh, 1999). Increasing reserves in number or size as a solution is limited by the large areas required (Mann and Plummer, 1993; Soulé and Sanjayan, 1998), by the currently limited area available for reserves (Lindenmayer and Franklin, 2002), and by the costs of reserve acquisition (Simberloff, 1998), particularly considering the scarcity of resources available for conservation (Skole and Compton, 1993).

The major limitation to reserve-centered conservation policies derives, however, from key biological and ecological processes that exceed the scale of reserves (Lindenmayer et al., 2000). Although it is often assumed that areas between reserves can ensure these processes, there is no clear indication that these more or less intensively managed in-between areas have played that role. Managed agriculture and forest areas and human settlements occupy $95 \%$ of the terrestrial environment (Pimentel et al., 1992). Urban growth is probably the major threat to biodiversity (Main et al., 1999). Agriculture-dominated landscapes 
have a low capacity to support diversity (Paoletti, 1999). In the tropics and many temperate regions managed areas outside reserves are expected to lose their capacity to support native species and ecosystems by 2050 (Soulé and Sanjayan, 1998). In the US destruction and degradation of habitats, introduction and spread of alien species, pollution, over exploitation, and diseases threaten biodiversity seriously (Wilcove et al., 1998).

Complementary to networks of reserves, management in intermediate areas needs to guarantee the processes required in the maintenance of biodiversity at larger scales. Although there are no signs of reversal on urban growth, there are prospects that agriculture and forestry can contribute to the conservation of biodiversity (Paoletti, 1995; Lotter, 2003; Pearce et al., 2003). Forestry, particularly, is under important changes worldwide through sustainable management and certification processes (Gullison, 2003). In the tropics, sustainable forestry is able to decrease loss of biodiversity (Pearce et al., 2003) and is also believed to maintain biodiversity in managed forests in other regions of the world (Wigley et al., 2000).

In the United States sustainability has become the dominant management philosophy in national forests (USDA Forest Service, 2000) and within the forest industry (Cantrell, 1998). The Sustainable Forestry Initiative (SFI) was launched in 1994 and is currently applied to 60 million hectares of forestland, $>90 \%$ of all the industry-owned forest in North America (American Forest \& Paper Association, 2005a). SFI is a system of principles, objectives, performance measures and indicators combing forestry with the protection of wildlife, plants, soil, water and air quality (American Forest \& Paper Association, 2005a). The current SFI standard is described in detail in American Forest \& Paper Association (2005b).

Following SFI, forest products companies are implementing landscapelevel measures such as establishment of buffer zones along streams, establishment of wildlife corridors, limitation in size of harvest units, and application of adjacency rules. Some of these requirements, as buffer zones along streams, were implemented prior to SFI and are part of state Best Management Practices and have been used as part of an effort to improve sustainability by SFI participants.

Among other objectives, SFI aims to "manage the quality and distribution of wildlife habitats and contribute to the conservation of biological diversity" (American Forest \& Paper Association, 2002). However, can industrial forests maintain biodiversity in levels comparable to other systems? Can industrial forests managed according to SFI guide- 
lines be considered as part of conservation strategies at the regional and national scales? In spite of all the optimism around sustainable forestry, the answers to questions like these cannot be given until the application of SFI measures is evaluated. Preliminary research indicates that industrial forests managed according to SFI principles can present high diversity and productivity of birds and high diversity of herpetofauna including many species of high conservation interest (Wigley et al., 2000). Other research indicates that, individually, some of the measures included in SFI have a positive effect on the maintenance of animal diversity in forested landscapes (e.g., Dickson and Huntley, 1987; Dickson et al., 1995; Lance and Phinney, 2001). Before more field data can be gathered and treated to analyze real impacts of sustainable forestry in intensively managed landscapes, other approaches can be developed in order to increase understanding of the effects of the SFI program on wildlife communities, particularly at broader scales.

It was observed previously that the implementation of the SFI program is changing landscape structure in east Texas (Azevedo, 2003). Assessment of the importance of these changes in terms of major processes, namely those related to wildlife and their habitats, requires specific treatment. The goal of this work is to study the implications of sustainable forestry on wildlife communities. More specifically, the objective of this research is to evaluate through modeling and simulation the changes caused by the application of landscape measures that have been adopted by companies in order to comply with SFI, in terms of quality, abundance and configuration of vertebrate species habitat in east Texas. We hypothesize that SFI changes composition, diversity, and spatial structure of habitats and that these changes increase diversity at the landscape scale.

\section{METHODS}

\section{Study Area}

The study area (5773 ha) was within the Chawanee Creek watershed in Angelina County, Texas, USA (Figure 1). Most of this area was owned by Temple-Inland Forest Products Corporation and managed for industrial forestry. Soils were predominantly Ultisols of the Rosenwall series and Alfisols of the Diboll series. The forest types included pine (mainly loblolly pine, Pinus taeda L.), 4727 ha (82\% of the area), hardwoods, 796 ha (14\%), and pine-hardwood mixed stands, 251 ha (4\%). 
FIGURE 1. Location of the study area.

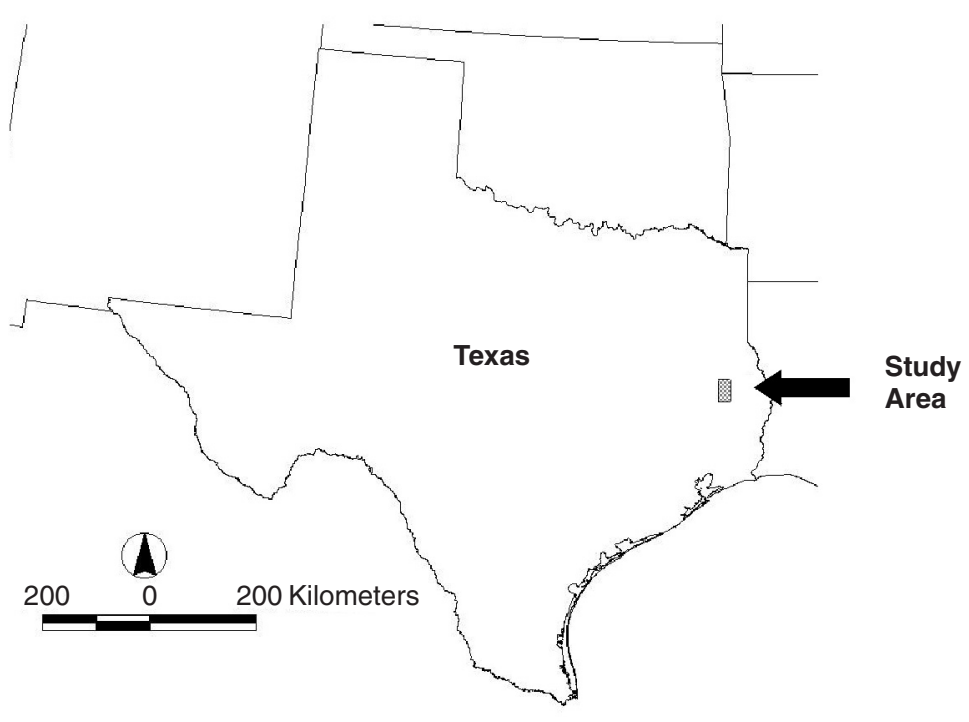

Approximately $70 \%$ of the area was managed by even-aged silviculture (clearcutting system).

\section{Landscape, Stand Modeling and Simulation}

A combination of landscape and stand models was used to simulate the dynamics of the landscape and its components in the study area. Landscape dynamics were simulated using HARVEST 6.0 (Gustafson and Rasmussen, 2002). This raster model simulates even- and uneven-aged silvicultural systems at the landscape scale incorporating parameters usually considered in forest management such as harvest unit size, total area harvested, rotation length, and green up interval, among others (Gustafson and Crow, 1999).

Five forest management types were considered in the study: (1) pineclearcutting, (2) hardwood-clearcutting, (3) pine-selection, (4) hardwood-selection, and (5) pine-hardwood-selection. Several growth and yield models were used to simulate stand-level dynamics: Compute P-Lob (Baldwin and Feduccia, 1987) for planted even-aged loblolly pine stands, SouthPro (Schulte et al., 1998) for uneven-aged pine, hardwood, and mixed pine-hardwood stands, and the southern variant of the 
Forest Vegetation Simulator (FVS) (Donnelly et al., 2001) for evenaged hardwood stands. These models produce estimates of height, basal area, density, biomass, and volume distributions by diameter classes as well as composition in the stand under different natural and management conditions.

Two landscape management scenarios were established. An SFI scenario was based on the application of SFI landscape measures, namely SMZs $\geq 30 \mathrm{~m}$ wide along perennial and intermittent streams, limits in harvest unit size (pine 49 ha; hardwoods 12 ha) and a three-year green up interval. A Non-SFI scenario was also established in the absence of all these rules, as a reference scenario. This scenario is constructed to compare SFI to past management and does not imply current practices elsewhere in the state under the guidelines of the state Best Management Practices.

We ran HARVEST for 400 years to analyze the behavior of the system in a long period of time. For each scenario, five replicate runs were conducted using independently generated random number seeds. A detailed description of the methodology is presented in Azevedo et al. (2005).

\section{Species Selection}

The vertebrate species that potentially occur in the ecological region encompassing the study area (83 herps, 132 birds, 51 mammals) were grouped into guilds based on their breeding and foraging requirements. Breeding and foraging requirements were specified using 42 binary variables based on vertical stratification of the pine, hardwood and pine-hardwood forest habitats (Table 1) and particular aspects such as tree bole and water surfaces. One breeding and one feeding variable were used for non-forest habitats.

Cluster analysis was used to define the guilds using the Ward's minimum variance clustering method with distances based upon Jaccard's coefficient of similarity (Lapointe and Legendre, 1994). A distance matrix, D, was obtained by subtracting similarity coefficient values from 1 (Lapointe and Legendre, 1994). Based upon the analysis of dendrograms, cluster composition, and combinations of habitat characteristics, 12 guilds were initially considered (Figure 2, Table 2). Four of these guilds were excluded from this study since they were comprised of species not associated with local conditions (Guilds 3 and 12), relied upon habitat characteristics difficult to estimate given the resolution of the data used (guild 11), or lacked published habitat 
TABLE 1. Breeding and foraging habitat layers and components for species classification.

\begin{tabular}{cll}
\hline Code & \multicolumn{1}{c}{ Name } & \multicolumn{1}{c}{ Description } \\
\hline 1 & Terrain surface and subsurface & Below ground to $15 \mathrm{~cm}$ above surface \\
2 & Understory & From $15 \mathrm{~cm}$ above surface to $0.5 \mathrm{~m}$ above surface \\
3 & Midstory & From $0.5 \mathrm{~m}$ to $8 \mathrm{~m}$ in height \\
4 & Tree canopy or overstory & Upwards from $8 \mathrm{~m}$ \\
5 & Tree bole & Dbh $\geq 20 \mathrm{~cm}$ \\
6 & Water & Water surfaces \\
7 & Elsewhere & Other features within forest (snags, logs, etc) \\
\hline
\end{tabular}

Modified from Short (1984).

FIGURE 2. Dendrogram for the clusters analysis with Ward's minimum variance and distances based upon Jaccard's coefficient of similarity. Numbers in the chart indicate cluster number. Cluster 3 , comprised of non-forest species is not represented.

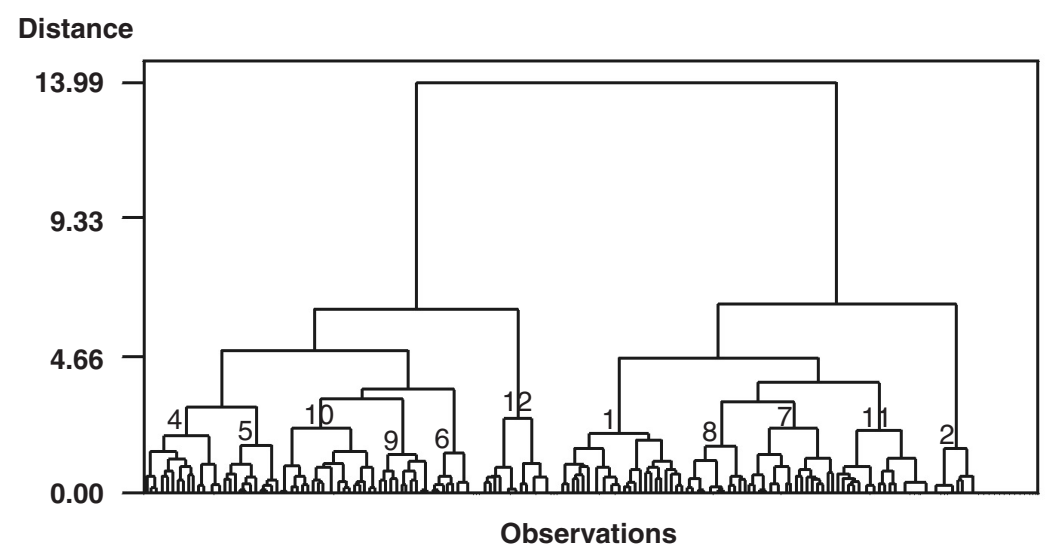

models (Guilds 6 and 11). For each of the eight guilds defined in the study, one species was selected to represent the general habitat requirements of the guild (Table 3): American beaver (Castor canadensis Kuhl, 1820), American woodcock (Scolopax minor J. F. Gmelin, 1789), pine warbler (Dendroica pinus Wilson, 1811), downy woodpecker (Picoides pubescens Linnaeus, 1766), barred owl (Strix varia Barton, 1799), wild turkey (Meleagris gallopavo silvestris Vieillot, 1817), fox 
TABLE 2. Composition and description of the clusters considered.

\begin{tabular}{cccccll}
\hline & \multicolumn{4}{c}{ Number of species } & & \\
\cline { 2 - 5 } Cluster & Total & Mammals & Birds & Herps & & Description \\
\hline 1 & 24 & 6 & 10 & 8 & & Ground hardwood species \\
2 & 21 & 6 & 2 & 13 & & Exclusive ground, generalists \\
3 & 94 & 12 & 49 & 33 & & Non-forest species \\
4 & 15 & 8 & 6 & 1 & & Cavity and canopy breeding \\
5 & 11 & 1 & 10 & 0 & & Exclusive cavity birds \\
6 & 10 & 1 & 8 & 1 & & Middle/high hardwood and mixed canopy birds \\
7 & 17 & 1 & 13 & 3 & & Ground feeding, diverse breeding \\
8 & 12 & 6 & 4 & 2 & & Ground and shrub, generalist \\
9 & 10 & 1 & 8 & 1 & Exclusive hardwood (diverse) \\
10 & 19 & 8 & 6 & 5 & Feeding in all layers, breeding diverse \\
11 & 18 & 1 & 1 & 16 & Water breeding, ground feeding species \\
12 & 15 & 0 & 15 & 0 & & Mid/high canopy breeding (no feeding in forest) \\
\hline
\end{tabular}

TABLE 3. Selected species and corresponding Habitat Suitability Index Models.

\begin{tabular}{cll}
\hline Cluster & Species & Model \\
\hline 1 & American beaver, Castor canadensis & Allen (1983) \\
2 & American woodcock, Scolopax minor & Cade (1985) \\
4 & Pine warbler, Dendroica pinus & Schroeder (1982a) \\
5 & Downy woodpecker, Picoides pubescens & Schroeder (1982b) \\
7 & Barred owl, Strix varia & Allen (1987b) \\
8 & Wild turkey, Meleagris gallopavo silvestris & Schroeder (1985) \\
9 & Fox squirrel, Sciurus niger & Allen (1982) \\
10 & Gray squirrel, Sciurus carolinensis & Allen (1987a) \\
\hline
\end{tabular}

squirrel (Sciurus niger Linnaeus, 1758) and gray squirrel (Sciurus carolinensis Gmelin, 1788).

\section{Habitat Suitability Index Models}

Habitat suitability at the stand and landscape levels was evaluated using Habitat Suitability Index (HSI) models (Schamberger et al., 1982), single-species models developed in the 1980s for quantifying impacts 
of land use changes in wildlife habitats. In spite of their limitations as habitat models (Roloff and Kernohan, 1999), HSI models allow habitat suitability quantification in a 0 to 1 scale assuming a direct linear relationship of HSI with carrying capacity of the land unit evaluated (US Fish and Wildlife Service, 1981). These are not carrying capacity models, however, since they do not include other variables affecting abundance such as predation, weather, and competition (Schamberger and O’Neil, 1986).

HSI models for the species selected to represent the guilds defined in this work (Table 3) were based upon structural and compositional attributes of the forest stands described by model variables. These variables were calculated directly or indirectly from simulated data provided by the growth and yield models and in few cases from assumptions based upon published data. Application of the HSI models is described in detail in Azevedo (2003). At the landscape level, HSI is calculated based upon GIS coverages resulting from the landscape simulations.

Five habitat suitability classes were defined based on HSI values: "unsuitable" (HSI $=0)$, "low" $(0<$ HSI $\leq 0.25)$, "medium" $(0.25<$ HSI $\leq$ $0.5)$, "high" $(0.5<$ HSI $\leq 0.75)$, and "very high" $(0.75<$ HSI $\leq 1)$. For each species and each year, maps of high and very high suitability habitats were generated and analyzed to quantify the landscape pattern using FRAGSTATS (McGarigal and Marks, 1995).

\section{RESULTS}

\section{Stand-Level Habitat Suitability}

Habitat suitability at the stand level depended on forest type, management type, and stand age (Figure 3). Suitability was often below the potential maximum values due to the effects of limiting components indicated in Table 4. American beaver was limited, minimally, by the presence of pine in pine-clearcutting and pine-selection stands and by reduced shrub cover in pine-clearcutting stands (food component). American woodcock in pine stands was limited by insufficient herbaceous and shrub cover and by low density of trees (cover component). Tree density was the only limiting factor in the remaining management types except in hardwood-clearcutting stands where vigorous vegetative growth following clearcutting and thinning operations was observed (Table 4).

The relatively low maximum value reached for pine warbler habitat 
FIGURE 3. Habitat suitability index values along stand development for some species. Values based on average site index. Notice $\mathrm{x}$-axes are not coincident among the plots. Management types refers to the combination of forest type and management system. (Man 1) pine-clearcutting, (Man 2) pine-selection, (Man 3) hardwood-clearcutting, (Man 4) hardwood-selection, and (Man 5) pine-hardwood-selection.
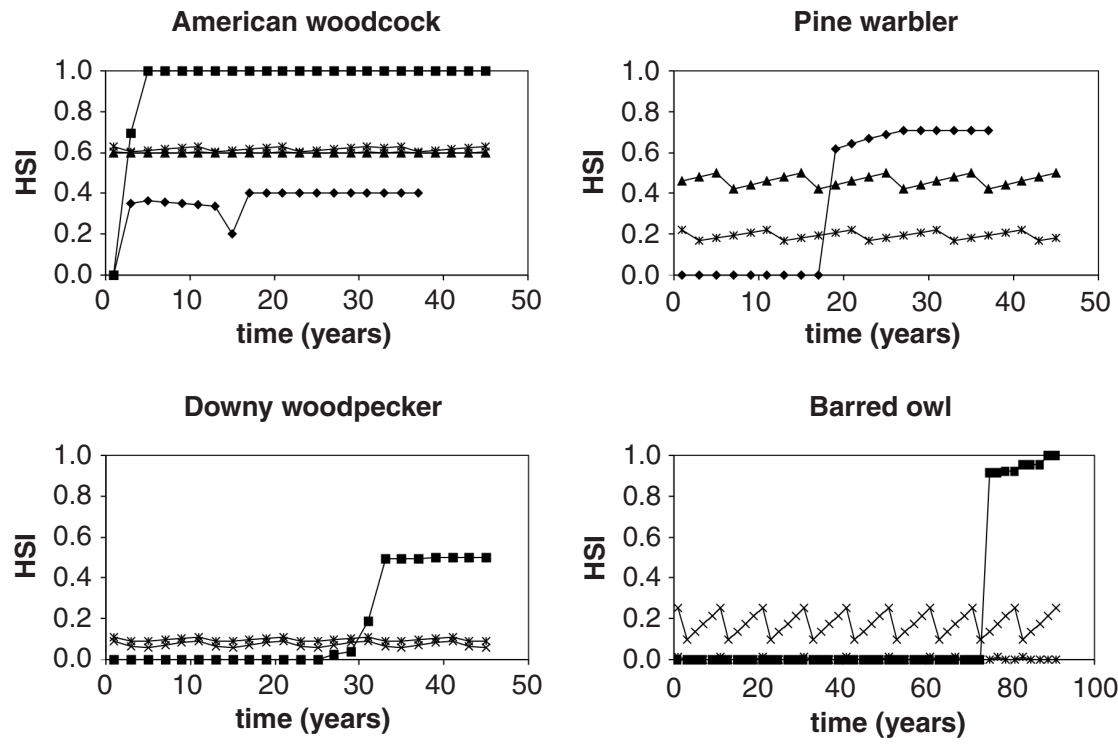

Fox squirrel
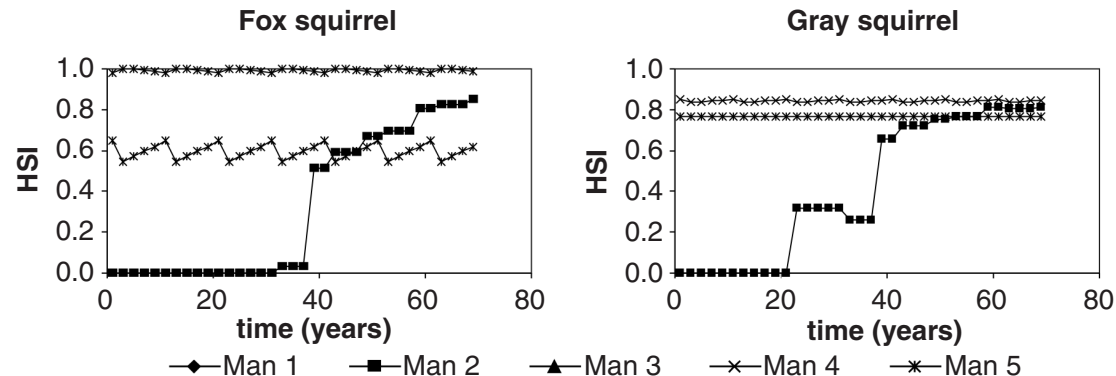

suitability in pine stands (Figure 3) was due to the "successional stage of stand" variable (Table 4). Maximum value is reached only for mature or old-growth stands. In the case of other pine management types, overstory pine cover was the major limiting factor. In mixed stands the presence of hardwoods further decreased the suitability of the stands. 
TABLE 4. Limiting variables in the Habitat Suitability Models per species and management type.

\begin{tabular}{|c|c|c|c|c|c|}
\hline \multirow[b]{2}{*}{ Species } & \multicolumn{5}{|c|}{ Management type } \\
\hline & 1 & 2 & 3 & 4 & 5 \\
\hline American beaver & $\begin{array}{l}\text { Shrub cover } \\
\text { Composition }\end{array}$ & Not limited & Composition & Not limited & Not limited \\
\hline $\begin{array}{l}\text { American wood- } \\
\text { cock }\end{array}$ & $\begin{array}{l}\text { Herbaceous and } \\
\text { shrub cover } \\
\text { Tree density }\end{array}$ & Not limited & Tree density & Tree density & Tree density \\
\hline Pine warbler & Stage & - & Pine cover & - & $\begin{array}{c}\text { Pine cover } \\
\text { Deciduous cover }\end{array}$ \\
\hline $\begin{array}{l}\text { Downy } \\
\text { woodpecker }\end{array}$ & - & $\begin{array}{c}\text { Basal area } \\
\text { Snags }\end{array}$ & - & Snags & Snags \\
\hline Barred owl & - & $\begin{array}{c}\text { Trees } \geq 51 \mathrm{~cm} \\
\text { Dbh }\end{array}$ & - & Dbh & Dbh \\
\hline Fox squirrel & - & Dbh & - & Not limited & Hard mast cover \\
\hline Gray squirrel & - & $\begin{array}{l}\text { Hard mast } \\
\% \text { Dbh }\end{array}$ & - & Not limited & Hard mast \% \\
\hline \multicolumn{6}{|l|}{$\begin{array}{l}\text { Eastern wild tur- } \\
\text { key }\end{array}$} \\
\hline Cover & Evergreens & Not limited & Evergreens & Not limited & Evergreens \\
\hline Summer & $\begin{array}{l}\text { Herbaceous } \\
\text { cover }\end{array}$ & $\begin{array}{l}\text { Herbaceous } \\
\text { cover }\end{array}$ & - & $\begin{array}{l}\text { Herbaceous } \\
\text { cover }\end{array}$ & $\begin{array}{l}\text { Herbaceous } \\
\text { cover }\end{array}$ \\
\hline $\begin{array}{l}\text { Fall/Winter/ } \\
\text { Spring }\end{array}$ & $\begin{array}{l}\text { Hard mast } \\
\text { Soft mast }\end{array}$ & Soft mast & $\begin{array}{l}\text { Hard mast } \\
\text { Soft mast }\end{array}$ & $\begin{array}{l}\text { Hard mast } \\
\text { Soft mast }\end{array}$ & $\begin{array}{l}\text { Hard mast } \\
\text { Soft mast }\end{array}$ \\
\hline
\end{tabular}

Management type refers to the combination of forest type and management system; management types are: (1) pine-clearcutting, (2) pine-selection, (3) hardwood-clearcutting, (4) hardwood-selection, and (5) pine-hardwood-selection.

For year-round habitat of downy woodpecker, basal area (food component) and density of snags larger than $15 \mathrm{~cm}$ dbh (reproduction component) were the limiting factors in the hardwood stands managed by the clearcutting system (Table 4). Basal area was often outside the $10-20 \mathrm{~m}^{2} /$ ha optimal interval. Snags were often abundant but their occurrence was not synchronized with optimum basal area. Snags larger than $15 \mathrm{~cm}$ dbh were the limiting factor in the uneven-aged stands. Maximum suitability values were never reached (Figure 3 ).

Barred owl reproductive habitat was mainly limited by mean dbh of overstory trees (Table 4). In the hardwood-clearcutting stands, the number of trees larger than $51 \mathrm{~cm}$ was even more limiting until around stand age 70. In hardwood-selection stands, harvests regularly decrease average dbh. Suitability was very high for stands older than 75 years in hardwood-clearcutting stands (Figure 3). 
Habitat suitability for fox squirrel in hardwood-clearcutting stands was limited by dbh of overstory trees (cover) and in pine-hardwood-selection stands was limited by cover of hard mast trees larger than $25.4 \mathrm{~cm}$ dbh (winter food). It was not limited in uneven-aged hardwood stands (Figure 3). Habitat suitability for gray squirrel in hardwood-clearcutting stands was partially limited by the proportion of canopy comprised of hard mast producing trees (winter food) and by dbh of overstory trees (cover). This was also the case in pine-hardwood-selection stands.

Wild turkey cover was limited in the management types with pine trees (Table 4). Summer habitat was strongly limited by the low herbaceous cover in all management types. Fall/winter/spring habitat was limited in the pine and mixed stands by lack of hard and soft mast producing trees.

\section{Landscape-Level Habitat Suitability}

The dynamics of the landscape structure presented a return interval of 30 years in the simulations (Azevedo et al., 2005). For this reason, all the results referred to a period of this duration.

The SFI and Non-SFI scenarios showed differences in habitat suitability for the species analyzed (Table 5). HSI value for pine warbler was lower in SFI than in Non-SFI. Given the similarity among runs, observed differences between management scenarios are statistically significant $(\mathrm{p}<0.001$; repeated measures ANOVA with management as a fixed effect and runs as random subjects). Habitat suitability for American beaver and American woodcock was slightly higher in the SFI landscape. There were substantial differences between scenarios in habitat suitability for wild turkey, fox squirrel, and gray squirrel. For these species, habitat suitability was very low in the Non-SFI scenario and relatively high in the SFI scenario. HSI values for barred owl and downy woodpecker were practically negligible in both scenarios. Habitat suitability was stable during the period simulated for all the species in both management scenarios.

\section{Spatial Pattern}

Highly suitable habitat for American woodcock was abundant only in the SFI landscape. This was distributed by very few patches spread over the landscape, with an extremely large edge length and few, small core areas (Table 6). Largest Patch Index practically equaled the Percent of Landscape indicating that near $100 \%$ of the area of this class was 
TABLE 5. Summary statistics of habitat suitability index (HSI) values for selected species under Sustainable Forestry Initiative (SFI) and Non-SFI management scenarios. Values refer to a 30-year simulation cycle.

\begin{tabular}{ccccccccc}
\hline & \multicolumn{4}{c}{ SFI scenario } & \multicolumn{5}{c}{ Non-SFI scenario } \\
\cline { 2 - 9 } Species & Mean & Min & Max & SD & Mean & Min & Max & SD \\
\hline American beaver $^{*}$ & 0.63 & 0.61 & 0.64 & 0.007 & 0.55 & 0.53 & 0.57 & 0.013 \\
American woodcock & 0.45 & 0.43 & 0.46 & 0.007 & 0.41 & 0.39 & 0.44 & 0.014 \\
Pine warbler & 0.19 & 0.15 & 0.23 & 0.027 & 0.23 & 0.17 & 0.28 & 0.033 \\
Downy woodpecker & 0.03 & 0.02 & 0.04 & 0.003 & 0.03 & 0.02 & 0.03 & 0.002 \\
Barred owl & 0.04 & 0.02 & 0.06 & 0.013 & 0.002 & 0.000 & 0.005 & 0.002 \\
Eastern wild turkey & 0.54 & 0.52 & 0.55 & 0.010 & 0.06 & 0.03 & 0.09 & 0.019 \\
Fox squirrel & 0.24 & 0.23 & 0.24 & 0.002 & 0.02 & 0.02 & 0.03 & 0.003 \\
Gray squirrel & 0.21 & 0.21 & 0.22 & 0.002 & 0.03 & 0.03 & 0.04 & 0.003 \\
\hline
\end{tabular}

${ }^{*}$ Calculated for the area within buffers only.

contained in a single patch (Table 6). This class corresponded mainly to the SMZs network established in the SFI scenario (Figure 4). Very high suitability habitat in the SFI scenario was comprised of several small and dispersed patches. In the Non-SFI scenario the same class occupied a larger area comprised mainly of two very large patches located in the central bottomland. Most of the landscape presented some suitability for American woodcock.

High suitability pine warbler habitat, the highest habitat class observed for the species, showed considerable fragmentation in the SFI scenario when compared to the Non-SFI scenario. In the SFI scenario it was comprised of more and smaller patches that were less aggregated, had more edges, less core area, and lower isolation (Table 6, Figure 4).

Fox and gray squirrel and wild turkey do not allow a fair comparison between scenarios since there was almost no quality habitat in Non-SFI as compared to SFI. Very high suitability habitat for fox squirrel and gray squirrel comprised the majority of suitable habitat in the SFI scenario. As in high suitability habitat for American woodcock, metrics reflected the characteristics of the SMZ network: few patches, one patch containing more than $90 \%$ of the class area, considerable total area occupied, low aggregation, small core area percentage, and small distances (Table 7).

HSI of wild turkey depends upon the combination of habitat components that have to be considered individually. Very high suitability 
TABLE 6. Selected landscape metrics for American woodcock "high" $(0.5<$ $\mathrm{HSI} \leq 0.75)$, and "very high" $(0.75<\mathrm{HSI} \leq 1)$ suitability habitat classes. All values are averages for three simulation runs and 15 observation dates.

\begin{tabular}{|c|c|c|c|c|c|c|}
\hline \multirow[b]{3}{*}{ Variable } & \multicolumn{4}{|c|}{ American woodcock } & \multirow{2}{*}{\multicolumn{2}{|c|}{$\begin{array}{c}\text { Pine warbler } \\
\text { "high" } \\
(0.5<\mathrm{HSI} \leq 0.75)\end{array}$}} \\
\hline & \multicolumn{2}{|c|}{$\begin{array}{c}\text { "high" } \\
(0.5<\mathrm{HSI} \leq 0.75)\end{array}$} & \multicolumn{2}{|c|}{$\begin{array}{c}\text { "very high" } \\
(0.75<\mathrm{HSI} \leq 1)\end{array}$} & & \\
\hline & SFI & Non-SFI & SFI & Non-SFI & SFI & Non-SFI \\
\hline Percentage of Landscape (\%) & 26.8 & 4.1 & 4.0 & 8.8 & 25.8 & 32.9 \\
\hline Patch Density (\#/100 ha) & 0.2 & 0.2 & 0.4 & 0.1 & 1.3 & 0.4 \\
\hline Edge Density (m/ha) & 69.7 & 4.8 & 6.8 & 6.6 & 37.4 & 19.7 \\
\hline Largest Patch Index (\%) & 26.8 & 1.6 & 0.7 & 5.0 & 2.9 & 13.7 \\
\hline Landscape Shape Index & 25.7 & 4.9 & 7.0 & 4.5 & 15.0 & 7.5 \\
\hline Mean Patch Area (ha) & 165.4 & 22.9 & 10.4 & 185.7 & 20.8 & 89.3 \\
\hline Mean Fractal Dimension Index & 1.13 & 1.10 & 1.09 & 1.13 & 1.10 & 1.09 \\
\hline $\begin{array}{l}\text { Area-Weighted Mean Fractal } \\
\text { Dimension Index }\end{array}$ & 1.39 & 1.07 & 1.10 & 1.15 & 1.13 & 1.13 \\
\hline $\begin{array}{l}\text { Core Area Percentage } \\
\text { of Landscape }(\%)\end{array}$ & 5.9 & 1.4 & 0.5 & 4.4 & 4.8 & 17.3 \\
\hline Mean Core Area (ha) & 36.3 & 7.8 & 1.2 & 93.0 & 3.9 & 47.0 \\
\hline Mean Core Area Index (\%) & 2.3 & 15.0 & 4.8 & 38.9 & 8.2 & 19.9 \\
\hline Mean Proximity Index & 1645.4 & 12.9 & 60.2 & 543.1 & 334.1 & 447.0 \\
\hline $\begin{array}{l}\text { Mean Euclidean Nearest } \\
\text { Neighbor Distance }(\mathrm{m})\end{array}$ & 153.0 & 722.8 & 160.5 & 192.4 & 80.6 & 212.2 \\
\hline $\begin{array}{l}\text { Interspersion and Juxtaposition } \\
\text { Index }(\%)\end{array}$ & 51.9 & 69.0 & 53.7 & 77.3 & 14.6 & 23.7 \\
\hline
\end{tabular}

cover habitat, very high suitability fall, winter, spring food habitat, and low suitability summer food/brood habitat in the SFI scenario (Table 8) shared the properties described above for networks of SMZs. This is of particular relevance in the case of cover habitat since it is the limiting component in both scenarios.

Suitable habitat for barred owl and downy woodpecker was extremely scarce for any of the management scenarios. Few, very small, and isolated very high suitability patches provided the only quality habitat for barred owl. In SFI, the SMZ network provided relatively abundant low suitability class habitat for both species although the HSI value for downy woodpecker was very small (Figure 3). In the case of American beaver, landscape metrics were very difficult to interpret and sometimes meaningless given the way HSI was calculated (within 0-100 and 100-200 m buffers). 
FIGURE 4. Examples of spatial pattern of habitat suitability classes for the study area in alternative management scenarios. Images refer to simulation year 156 .

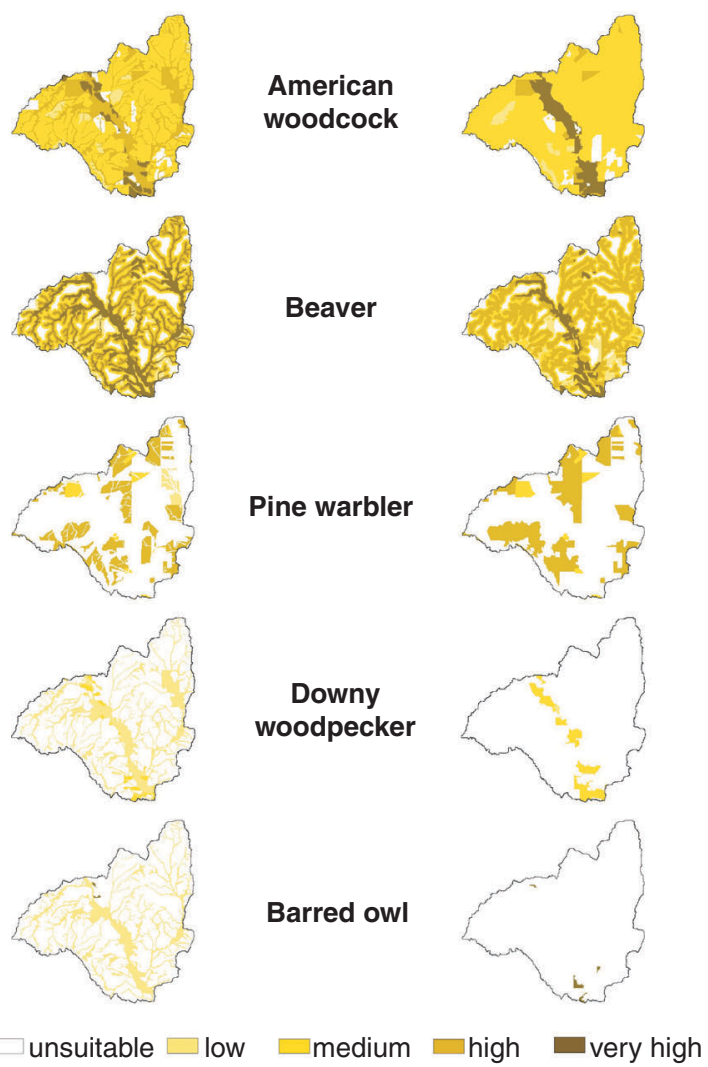


FIGURE 4 (continued)

SFI

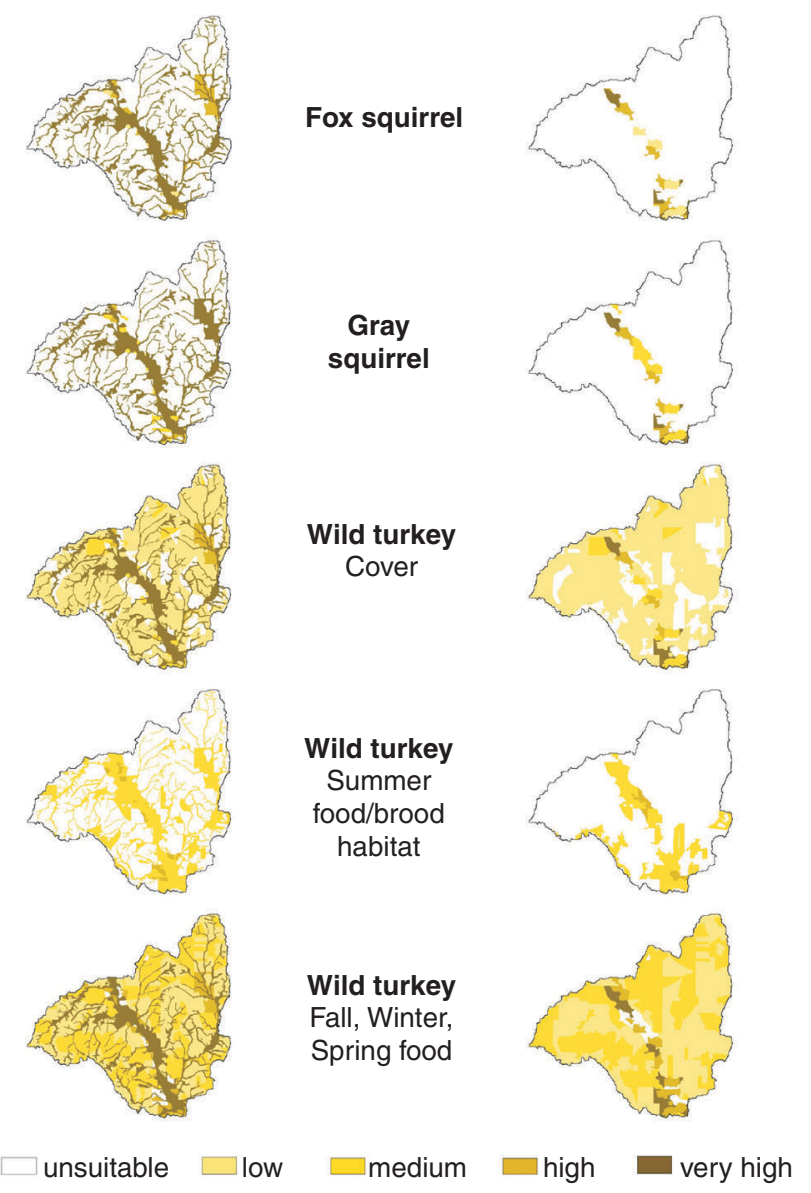

\section{DISCUSSION}

\section{Landscape-Level Habitat Suitability}

Differences between landscapes in terms of landscape-level HSI are explained by differences in composition of forest and management types (Table 9) and by stand level habitat suitability (Figure 3). Certain 
TABLE 7. Selected landscape metrics for fox and gray squirrel "high" $(0.5<\mathrm{HSI}$ $\leq 0.75)$, and "very high" $(0.75<\mathrm{HSI} \leq 1)$ suitability habitat classes. All values are averages for three simulation runs and 15 observation dates.

\begin{tabular}{|c|c|c|c|c|c|c|c|c|}
\hline \multirow[b]{3}{*}{ Variable } & \multicolumn{4}{|c|}{ Fox squirrel } & \multicolumn{4}{|c|}{ Gray squirrel } \\
\hline & \multicolumn{2}{|c|}{$\begin{array}{c}\text { "high" } \\
(0.5<\mathrm{HSI} \leq 0.75)\end{array}$} & \multicolumn{2}{|c|}{$\begin{array}{c}\text { "very high" } \\
(0.75<\mathrm{HSI} \leq 1)\end{array}$} & \multicolumn{2}{|c|}{$\begin{array}{c}\text { "high" } \\
(0.5<\mathrm{HSI} \leq 0.75)\end{array}$} & \multicolumn{2}{|c|}{$\begin{array}{c}\text { "very high" } \\
(0.75<\mathrm{HSI} \leq 1)\end{array}$} \\
\hline & SFI & Non-SFI & SFI & Non-SFI & SFI & Non-SFI & SFI & Non-SFI \\
\hline $\begin{array}{l}\text { Percentage of } \\
\text { Landscape (\%) }\end{array}$ & 2.9 & 2.2 & 22.1 & 0.9 & 0.7 & 1.7 & 24.4 & 1.7 \\
\hline Patch Density ( $\# / 100$ ha) & 0.4 & 0.1 & 0.1 & 0.1 & 0.1 & 0.1 & 0.1 & 0.1 \\
\hline Edge Density $(\mathrm{m} / \mathrm{ha})$ & 6.2 & 3.3 & 70.5 & 1.8 & 1.8 & 2.4 & 69.7 & 2.9 \\
\hline Largest Patch Index (\%) & 0.7 & 0.9 & 22.0 & 0.5 & 0.2 & 0.8 & 24.3 & 0.7 \\
\hline Landscape Shape Index & 7.0 & 4.3 & 28.6 & 3.9 & 4.3 & 3.6 & 26.9 & 4.5 \\
\hline Mean Patch Area (ha) & 8.1 & 26.4 & 154.9 & 13.3 & 5.4 & 30.2 & 169.6 & 17.8 \\
\hline $\begin{array}{l}\text { Mean Fractal Dimension } \\
\text { Index }\end{array}$ & 1.11 & 1.12 & 1.17 & 1.13 & 1.10 & 1.11 & 1.17 & 1.13 \\
\hline $\begin{array}{l}\text { Area-Weighted Mean } \\
\text { Fractal Dim. Index }\end{array}$ & 1.09 & 1.12 & 1.41 & 1.12 & 1.10 & 1.12 & 1.40 & 1.12 \\
\hline $\begin{array}{l}\text { Core Area Percentage } \\
\text { of Landscape (\%) }\end{array}$ & 0.4 & 0.5 & 3.2 & 0.1 & 0.0 & 0.4 & 4.7 & 0.3 \\
\hline Mean Core Area (ha) & 1.0 & 5.8 & 22.5 & 1.6 & 0.1 & 6.7 & 32.8 & 3.1 \\
\hline $\begin{array}{l}\text { Mean Core Area Index } \\
(\%)\end{array}$ & 3.5 & 13.8 & 1.8 & 5.6 & 1.1 & 16.5 & 2.3 & 8.4 \\
\hline Mean Proximity Index & 56.4 & 17.4 & 1193.6 & 2.2 & 4.8 & 9.0 & 1392.3 & 11.5 \\
\hline $\begin{array}{l}\text { Mean Eucl. Nearest } \\
\text { Neighbor Distance }(\mathrm{m})\end{array}$ & 172.6 & 670.0 & 128.1 & 1227.2 & 641.9 & 1214.1 & 126.3 & 715.4 \\
\hline $\begin{array}{l}\text { Interspersion and } \\
\text { Juxtaposition Index (\%) }\end{array}$ & 58.4 & 54.1 & 19.4 & 54.3 & 86.2 & 75.0 & 17.2 & 76.9 \\
\hline
\end{tabular}

SFI measures could have strong influence on landscape structure. For example, the implementation of SMZs in pine stands will eventually change these areas to foster hardwood domination with effects in terms of habitat suitability at the stand but also the overall level. The SFI landscape is comprised of stands of five different management types whereas Non-SFI presents only three types (Table 9). Hardwood cover is more abundant in SFI than in Non-SFI. Approximately 1000 ha of hardwoods in SFI result from the "conversion" of pine into hardwoods within SMZ buffer strips. Evenness among management types is also higher in SFI.

Overall habitat suitability for wild turkey, fox and gray squirrels was very low in the Non-SFI scenario because hardwood stands had the 
TABLE 8. Selected landscape metrics for wild turkey cover, Summer food/ brood, and Fall/Winter/Spring "high" $(0.5<\mathrm{HSI} \leq 0.75)$, and "very high" $(0.75<$ $\mathrm{HSI} \leq 1)$ suitability habitat classes. All values are averages for three simulation runs and 15 observation dates.

\begin{tabular}{|c|c|c|c|c|c|c|c|c|c|c|}
\hline \multirow[b]{3}{*}{ Variable } & \multicolumn{4}{|c|}{ Cover } & \multirow{2}{*}{\multicolumn{2}{|c|}{$\begin{array}{c}\begin{array}{c}\text { Summer } \\
\text { food/brood }\end{array} \\
\text { "high" } \\
(0.5<\mathrm{HSI} \leq 0.75) \\
\end{array}$}} & \multicolumn{4}{|c|}{ Fall/Winter/Spring } \\
\hline & \multicolumn{4}{|c|}{$\begin{array}{cc}\text { "high" } & \text { "very high" } \\
(0.5<\mathrm{HSI} \leq 0.75) & (0.75<\mathrm{HSI} \leq 1)\end{array}$} & & & \multicolumn{2}{|c|}{$\begin{array}{c}\text { "high" } \\
(0.5<\mathrm{HSl} \leq 0.75)\end{array}$} & \multicolumn{2}{|c|}{$\begin{array}{c}\text { "very high" } \\
(0.75<\mathrm{HSI} \leq 1)\end{array}$} \\
\hline & SFI & Non-SFI & SFI & Non-SFI & SFI & Non-SFI & SFI & Non-SFI & SFI & Non-SFI \\
\hline $\begin{array}{l}\text { Percentage of } \\
\text { Landscape }(\%)\end{array}$ & 2.6 & 1.4 & 22.5 & 2.0 & 1.1 & 2.1 & 4.1 & 4.5 & 23.1 & 3.4 \\
\hline $\begin{array}{l}\text { Patch Density } \\
(\# / 100 \text { ha) }\end{array}$ & 0.3 & 0.1 & 0.1 & 0.1 & 0.2 & 0.1 & 0.5 & 0.1 & 0.1 & 0.1 \\
\hline $\begin{array}{l}\text { Edge Density } \\
(\mathrm{m} / \mathrm{ha})\end{array}$ & 5.2 & 2.0 & 70.7 & 3.1 & 2.6 & 2.9 & 8.4 & 4.9 & 70.8 & 4.4 \\
\hline $\begin{array}{l}\text { Largest Patch } \\
\text { Index }(\%)\end{array}$ & 0.7 & 0.8 & 22.5 & 0.9 & 0.2 & 1.0 & 0.7 & 2.2 & 23.0 & 1.3 \\
\hline $\begin{array}{l}\text { Landscape Shape } \\
\text { Index }\end{array}$ & 6.2 & 3.2 & 28.4 & 4.5 & 5.0 & 3.8 & 8.1 & 4.5 & 28.2 & 4.9 \\
\hline $\begin{array}{l}\text { Mean Patch Area } \\
\text { (ha) }\end{array}$ & 8.7 & 31.5 & 157.7 & 21.0 & 5.8 & 33.7 & 8.3 & 63.8 & 160.3 & 31.2 \\
\hline $\begin{array}{l}\text { Mean Fractal } \\
\text { Dimension Index }\end{array}$ & 1.10 & 1.11 & 1.17 & 1.12 & 1.09 & 1.09 & 1.10 & 1.12 & 1.17 & 1.12 \\
\hline $\begin{array}{l}\text { Area-Weighted } \\
\text { Mean Fractal Dim. } \\
\text { Index }\end{array}$ & 1.09 & 1.11 & 1.41 & 1.12 & 1.09 & 1.10 & 1.09 & 1.13 & 1.41 & 1.12 \\
\hline $\begin{array}{l}\text { Core Area } \\
\text { Percentage of } \\
\text { Landscape (\%) }\end{array}$ & 0.4 & 0.3 & 3.3 & 0.4 & 0.0 & 0.4 & 0.4 & 1.5 & 3.6 & 0.9 \\
\hline $\begin{array}{l}\text { Mean Core Area } \\
\text { (ha) }\end{array}$ & 1.2 & 7.6 & 23.4 & 4.4 & 0.2 & 6.4 & 0.9 & 21.6 & 25.2 & 8.4 \\
\hline $\begin{array}{l}\text { Mean Core Area } \\
\text { Index (\%) }\end{array}$ & 4.1 & 17.3 & 1.8 & 10.1 & 1.3 & 13.3 & 3.4 & 25.3 & 1.9 & 15.3 \\
\hline $\begin{array}{l}\text { Mean Proximity } \\
\text { Index }\end{array}$ & 65.0 & 7.3 & 1262.1 & 15.7 & 9.2 & 73.8 & 53.5 & 123.5 & 1409.5 & 28.9 \\
\hline $\begin{array}{l}\text { Mean Eucl. } \\
\text { Nearest Neighbor } \\
\text { Distance }(\mathrm{m})\end{array}$ & 260.2 & 1487.0 & 126.3 & 672.9 & 467.2 & 1113.2 & 146.4 & 504.5 & 124.9 & 366.8 \\
\hline $\begin{array}{l}\text { Interspersion and } \\
\text { Juxtaposition Index } \\
\text { (\%) }\end{array}$ & 69.4 & 77.7 & 61.4 & 78.9 & 63.8 & 52.5 & 70.8 & 93.6 & 72.9 & 91.5 \\
\hline
\end{tabular}

highest suitability whereas pine stands had very low suitability (Figure 3 for fox and gray squirrel). These changes in forest types, however, do not affect pine warbler in the same proportion. Although there was considerably more pine stands in Non-SFI, the habitat type where stand level habitat suitability could reach the maximum, landscape-level habitat suitability increased only slightly in this scenario. This was due to 
TABLE 9. Area by management type in the SFI and Non-SFI scenarios.

\begin{tabular}{|c|c|c|c|c|c|c|}
\hline \multirow[b]{2}{*}{ Management type } & \multirow[b]{2}{*}{ Forest type } & \multirow[b]{2}{*}{$\begin{array}{l}\text { Silvicultural } \\
\text { system }\end{array}$} & \multicolumn{2}{|c|}{ SFI } & \multicolumn{2}{|c|}{ Non-SFI } \\
\hline & & & $\begin{array}{c}\text { Area } \\
\text { (ha) }\end{array}$ & $\begin{array}{c}\text { Area } \\
(\%)\end{array}$ & $\begin{array}{l}\text { Area } \\
\text { (ha) }\end{array}$ & $\begin{array}{c}\text { Area } \\
(\%)\end{array}$ \\
\hline 1 & Pine & clearcutting & 3964.3 & 68.7 & 4993.3 & 86.5 \\
\hline 2 & Hardwood & clearcutting & 265.8 & 4.6 & 595.2 & 10.3 \\
\hline 3 & Pine & selection & 164.4 & 2.8 & 183.5 & 3.2 \\
\hline 4 & Hardwood & selection & 1260.4 & 21.8 & - & - \\
\hline 5 & Mixed & selection & 116.9 & 2.0 & - & - \\
\hline
\end{tabular}

the relatively low maximum stand-level suitability ( $\max H S I=0.7$ ), the relatively short period of time (11 years) that pine stands had high suitability values, and the fact that young pine stands ( $<19$ years) were unsuitable.

The low landscape-level suitability values for barred owl and downy woodpecker (Table 5) reflected the rarity of suitable habitat and the low HSI value for the SMZ network in the SFI scenario for these species. High habitat suitability for barred owl in a few small areas under the Non-SFI scenario (Figure 4) resulted from the application of adjacency constraints in the hardwood areas that allow some small hardwood fragments to grow for longer periods of time. There was no high or very high suitability habitat for downy woodpeckers under either management scenario.

American beaver habitat quality was higher in the SFI than in the Non-SFI scenario. This was due to the fact that stands under hardwood-selection and pine-hardwood-selection management, which were always highly suitable (HSI $=1$ ), were absent from the Non-SFI scenario.

\section{Spatial Pattern}

The SFI program as simulated in this work changed the spatial pattern of habitats in two ways: (1) fragmentation and (2) establishment of narrow and elongated areas in a network configuration. The first effect was observed for pine warbler and the second for American woodcock, fox and gray squirrel, and wild turkey, and for the less suitable habitat of downy woodpecker and barred owl. Implications of these changes are 
unknown but can be speculated based upon the knowledge of the life history of the species analyzed.

SFI created fragmentation of pine warbler habitat mainly by dissecting large pine stands through the establishment of SMZs (Table 6, Figure 4). SMZs are, however, forested and permanent in the landscape and are also usually narrow. Although the effects of this configuration on pine warbler is unknown, the documented behavior of the species, including its ability to use pine trees within hardwood stands (Rodewald et al., 1999) indicates that this fragmentation is unlikely to have considerable effects on pine warbler populations (see discussion in Azevedo et al., 2005).

Suitable winter habitat of American woodcock was primarily associated with the network of riparian buffers. The species uses open fields, recently harvested stands, and dense hardwood stands (Keppie and Whiting, 1994; Berdeen and Krementz, 1998) but bottomlands are among the preferred habitats (Dessecker and McAuley, 2001). The fact that riparian buffers were widely spread over the study area and had a large amount of interface (edges) with other habitat types is likely to benefit the species.

Fox squirrels prefer edges (Alexander, 1994; Derge and Yahner, 2000) and can use open agricultural fields among habitat patches (Nupp and Swihart, 2000). Management practices to improve fox squirrel habitat in East Texas involve design of patches to maximize edge proportion as well as corridors for movement (Alexander, 1994). Gray squirrel is considered a more interior species than fox squirrel (Derge and Yahner, 2000; Zollner, 2000) but is common in a wide range of habitat types including urban and open systems such as cemeteries and campus when hardwoods are present (Williamson, 1983). The species is affected by habitat patch size and isolation in agriculturally fragmented landscapes (Goheen et al., 2003), where patches larger than 5 ha connected by corridors, including riparian strips, to other forest areas are required (Nupp and Swihart, 2000). SMZs in the SFI scenario provided such corridors. Fischer and Holler (1991) found narrow hardwood buffers along streams to be important components of gray squirrel habitat in Alabama. Dickson and Huntley (1987) found SMZs to be preferable habitat of both squirrel species in East Texas.

The network of SMZs and the adjacent mixed pine-hardwood stands provided simultaneously the three components of the habitat required by wild turkey including cover, the critical component in the overall HSI. Turkeys are not confined to particular habitats and move frequently among them. High edge length appeared positively related to 
turkey densities in New York State (Glennon and Porter, 1999). In the South, SMZs are used by turkeys during all seasons and are key habitat to sustain viable populations in managed pine forests (Burk et al., 1990; Hurst and Dickson, 1992). Predation of turkeys in stream valleys and in forest edges can, however, be higher than in other habitats (Thogmartin and Schaeffer, 2000).

Downy woodpecker is considered a generalist (Whitaker and Montevecchi, 1999) and frequently uses open habitats, residential areas, and forest edges (Jackson and Ouellet, 2002), as well as buffer strips (Dickson et al., 1995). There were fewer and smaller patches of the most suitable habitat for downy woodpeckers in the SFI scenario than in the Non-SFI scenario. Schroeder (1982b) suggested 4 ha as the minimum size of potentially useable habitat for downy woodpecker. Although these small high-quality patches were contiguous to the large amount of low-quality habitat associated with the SMZ network it is not clear whether habitat unit size would be a concern.

There were only isolated small patches of suitable habitat for barred owl in either scenario. There was, however, a considerable amount of lower quality habitat in the SFI scenario within the SMZ network.

Given the dependence of beaver on streams and the similar suitabilities of different types of stands, the spatial distribution of beaver habitat differed little between the two scenarios. The SFI landscape, however, did favor the species by providing continuous and permanent forest cover along the streams.

\section{SMZs}

SMZs are crucial elements of the SFI scenario. Although initially implemented to control water quality, their role in wildlife conservation, particularly in short rotation forests, has been recognized. SMZs increase diversity of habitats by creating edges (Thurmond and Miller, 1994), habitat features such as den trees and snags (Wigley and Roberts, 1997), and mast- and forage-producing plants (Dickson et al., 1995). Several species that are not able to use pine habitats can be preserved only due to the presence of SMZs (Thurmond and Miller, 1994). SMZs are able to retain a large percentage of the local species that otherwise would be largely lost after harvesting (Cockle and Richardson, 2003; Vesely and McComb, 2002). At the landscape level, SMZs are important also in terms of movement of organisms within networks (Machtans et al., 1996; Burbrink et al., 1998) and spread of organisms over areas of less suitable habitats (Fischer and Holler, 1991). 
A major issue of SMZs is their width. Buffers tend to maintain generalist and edge species. Some interior species are preserved as well in SMZs but others are excluded from relatively narrow SMZs (Thurmond and Miller, 1994; Thurmond et al., 1995; Meiklejohn and Hughes, 1999). In East Texas there is a positive relation between bird communities (breeding abundance and richness) and buffer width (Dickson et al., 1995). Narrow SMZs (15-25 m) are used by species associated with young pine stands and edge habitats whereas wide zones $(50-95 \mathrm{~m})$ were occupied by species associated with mature forest (Dickson et al., 1995). A minimum width of $30 \mathrm{~m}$ and a preferred width of $50 \mathrm{~m}$ are suggested to increase breeding birds in pine plantations. Rudolph and Dickson (1990) suggest $30 \mathrm{~m}$ to maintain reptile and amphibian richness in managed pine stands. The highest density of downy woodpeckers in buffer zones in recently harvested pine stands was observed in intermediate and wide zones (30-40 m and 50-95 m) (Dickson et al., 1995). Dickson and Huntley (1987) found abundant squirrels in buffers $>50 \mathrm{~m}$ wide in East Texas in contrast to smaller buffers. In Mississippi turkeys use all sizes of SMZs (30-45, 84-104, and 170-179 m) for traveling, roosting, feeding, loafing and summer cover (Burk et al., 1990).

The SMZs in our study were relatively narrow, averaged approximately $50 \mathrm{~m}$ and ranged from $30 \mathrm{~m}$ to more than $250 \mathrm{~m}$. Although a minimum width is difficult to define and is species dependent, the SMZs width in this study appears not limiting with respect to the species considered in this study based on the habitat modeling.

\section{Habitat Improvement}

The landscape managed according to the SFI guidelines was able to offer suitable habitat for species representing a wider range of habitat requirements than the Non-SFI scenario. Some recommendation can be presented, however, in order to improve habitat components at the stand and landscape levels.

At the stand level, extended rotations and retention of individual or clustered trees or snags in harvested stands will improve barred owl, downy woodpecker, and pine warbler habitat suitability. Changing target distributions and maximum size of trees to harvest will improve habitat suitability for downy woodpeckers, barred owls, fox, and gray squirrels in uneven-aged stands. If these measures are directed to mast producer trees, habitat for turkey and squirrels will also be improved. Management of herbaceous and shrub vegetation will also improve habitat for American woodcock and turkey. 
Long rotations are used to increase structural complexity in managed forests (Franklin et al., 1997) and have been defended to increase breeding bird diversity (Conner et al., 1979). Partial retention either in the form of dead or live isolated or clustered trees is an important measure for the maintenance of birds in forests (Dickson et al., 1983; Merrill et al., 1998; Lance and Phinney, 2001). Retention is a central procedure in conservation of forest diversity (e.g., Hunter, 1990; Franklin et al., 1997; Lindenmayer and Franklin, 1997).

A proper evaluation of the spatial characteristics of pine warbler's habitat is contingent on better understanding of the sensitivity of the warbler to patch size and edges, for which considerable disagreement exists in the literature (Rodewald et al., 1999; Boulinier et al., 1998; McIntyre, 1995; Noss, 1991). If pine warbler was indeed sensitive to SMZ edges and a 30-ha minimum size was required for core area, as discussed in Azevedo (2005), the landscape under the SFI scenario would provide no pine warbler suitable habitat. This situation could be alleviated by increasing the clearcut size, as argued elsewhere to reduce fragmentation (Hagan et al., 1997). However, given the high density of the SMZ network it is difficult to implement large-size clearcuts in this scenario. A possible alternative is to set aside large mature pine stands in the landscape as pine warbler breeding habitat.

Barred owls require large unfragmented mature forest areas (Mazur and James, 2000), although minimum habitat area is unknown (Allen, 1987b). In addition to the recommendations for stand level management mentioned previously, it is important to consider aggregation of hardwood stands to create reasonably large areas of suitable breeding habitat. Bottomlands are good candidates for management of barred owl habitat; the upland SMZs can also be managed for that purpose as well through hardwood-selection management.

Conservation of some of the species considered here rely upon SMZs, namely fox squirrel (Alexander, 1994), gray squirrel (Fischer and Holler, 1991), and turkey (Burk et al., 1990; Hurst and Dickson, 1992). Literature also suggests that downy woodpeckers benefit from SMZs after clearcutting (Dickson et al., 1995).

Combination of the SFI measures and additional measures for particular circumstances can help better achieve the biodiversity objectives in forest management. SMZs, retention, and long rotations in portions of a landscape appear to create the stand and landscape habitat structural features that contribute to the maintenance of habitat for species of diverse habitat requirements and hence the overall biodiversity. 


\section{CONCLUSION}

SFI provides a group of measures that benefit biodiversity in managed landscapes. The species selected in this work indicated that habitat suitability of the landscape in general increased as a result of the implementation of the SFI measures. They indicated also that there was more diversity and evenness of habitat conditions in the study area and that the habitat landscape structure was usually not limiting for these species.

The landscape under SFI, however, did not support mature pine and hardwood stands that are known for the diversity they retain and particular habitat they provide for species that are exclusively associated with these environments such as the red-cockaded woodpecker (Picoides borealis) and the brown-headed nuthatch (Sitta pusilla) in pine stands and the prothonotary warbler (Protonotaria citrea) and Swainson's warbler (Limnothlypis swainsonii) in hardwoods (Conner and Dickson, 1997). Habitat for species like these can, however, be maintained through landscape and stand management. These measures can potentially be incorporated into the SFI program as essential to wildlife conservation, one of the major aims of SFI.

Most of the species considered in this study benefited directly from the implementation of SMZs in the SFI scenario and some of them found no suitable habitat in the alternative scenario. SMZs, however, increased fragmentation of the pine cover, which might limit the habitat for the species dependent on large blocks of pine habitats of older ages. The corresponding increase in edges in the landscape could potentially increase edge-related processes, such as nest predation and parasitism (Conner and Dickson, 1997). These edge-related processes, however, are landscape context dependent (Donovan et al., 1997); the low edge contrast between the SMZs covered with mature forests and the adjacent pine stands is unlikely to result in significant negative impact associated with the edge effects.

Results of this simulation study show that southern forested landscapes managed under the SFI program appear superior in supporting biodiversity, through providing greater amount of suitable habitats for the array of a set of vertebrate species representing the spectrum of habitat requirements, than landscapes managed under more traditional forest management programs. Given the larger extent of forests managed by forest products companies committed to the SFI in the South, this program can play an important role in the conservation of biodiversity at the local and broader scales. 


\section{REFERENCES}

Alexander, B.G. 1994. Fox squirrel management in East Texas. Texas Parks and Wildlife, Austin, TX.

Allen, A.W. 1982. Habitat suitability index models: Fox squirrel. USDI Fish Wild. Serv. FWS/OBS 82/10.18.

Allen, A.W. 1983. Habitat suitability index models: Beaver. USDI Fish Wildl. Serv. FWS/OBS-82/10.30. Revised.

Allen, A.W. 1987a. Habitat suitability index models: Gray squirrel, revised. U.S. Fish Wildl. Serv. Biol. Rep. 82(10.135).

Allen, A.W. 1987b. Habitat suitability index models: Barred owl. USDI Fish Wild. Serv. Biol. Rep. 82(10.143).

American Forest \& Paper Association. 2002. 2002-2004 SFI standard and verification procedures. AF\&PA, Washington, DC.

American Forest \& Paper Association. 2005a. The Sustainable Forestry Initiative ${ }^{\circledR}$ 10th Annual Progress Report. AF\&PA, Washington, DC.

American Forest \& Paper Association. 2005b. Sustainable Forestry Initiative ${ }^{\circledR}$ (SFI) Standard 2005-2009 edition. AF\&PA, Washington, DC.

Azevedo, J.C. 2003. A comparison of the environmental effects of traditional intensive forestry and the Sustainable Forestry Initiative: A modeling approach at the landscape level. Unpublished Ph.D. Dissertation, Texas A\&M University, College Station, TX.

Azevedo, J.C., X.B. Wu, M.G. Messina and R.F. Fisher. 2005. Assessment of sustainability in intensively managed forested landscapes: A case study in east Texas. Forest Sci. 51(4): 321-333.

Baldwin, V.C. and D.P. Feduccia. 1987. Loblolly pine growth and yield prediction for managed west gulf plantations. USDA For. Serv. Res. Pap. SO-236.

Berdeen, J.B. and D.G. Krementz. 1998. The use of fields at night by wintering American woodcock. J. Wildl. Manage. 62: 939-947.

Boulinier, T., J.D. Nichols, J.E. Hines, J.R. Sauer, C.H. Flather and K.H. Pollock.1998. Higher temporal variability of forest breeding bird communities in fragmented landscapes. Proc. Natl. Acad. Sci. 95: 7497-7501.

Burbrink, F.T., C.A. Phillips and E.J. Heske. 1998. A riparian zone in southern Illinois as a potential dispersal corridor for reptiles and amphibians. Biol. Conserv. 86: 107-115.

Burk, J.D., G.A. Hurst, D.R. Smith, B.D. Leopold and J.D. Dickson. 1990. Wild turkey use of streamside management zones in loblolly pine plantations. In: pp. 6:84-89. Proceedings of the Sixth National Wild Turkey Symposium. National Wild Turkey Federation, Edgefield, SC.

Cade, B.S. 1985. Habitat suitability index models: American woodcock (wintering). U.S. Fish Wildl. Serv. Biol. Rep. 82(10.105).

Cantrell, R. 1998. AF\&PA's sustainable forestry initiative ${ }^{\mathrm{SM}}-\mathrm{A}$ bold new program that works for the U.S.A. Biomass and Bioenergy 14(4): 325-328.

Cockle, K.L. and J.S. Richardson. 2003. Do riparian buffer strips mitigate the impacts of clearcutting on small mammals? Biol. Conserv. 113: 133-140.

Conner, R.N. and J.G. Dickson. 1997. Relationships between bird communities and forest age, structure, species composition and fragmentation in the West Gulf Coastal Plain. Texas Journal of Science 49: 123-138. 
Conner, R.N., J.W. Via and I.D. Prather. 1979. Effects of pine-oak clearcutting on winter and breeding birds in southwest Virginia. Wilson Bull. 91: 301-316.

Derge, K.L. and R.H. Yahner. 2000. Ecology of sympatric fox squirrels (Sciurus niger) and gray squirrels (S. carolinensis) at forest-farmland interfaces of Pennsylvania. Am. Midl. Nat. 143: 355-369.

Dessecker, D.R. and D.G. McAuley. 2001. Importance of early successional habitat to ruffed grouse and American woodcock. Wildl. Soc. Bull. 29: 456-465.

Dickson, J.G. and J.C. Huntley. 1987. Riparian zones and wildlife in Southern forests: The problem and squirrel relationships. In: pp. 37-39. Dickson, J.G. and O.E. Maughan (eds). Managing Southern Forests for Wildlife and Fish, a Proceedings. USDA For. Serv. Gen. Tech. Rep. SO 065, New Orleans, LA.

Dickson, J.G., R.N. Connor and J.W. Williamson. 1983. Snag retention increases bird use of a clearcut. J. Wildl. Manage. 47: 799-804.

Dickson, J.G., J.H. Williamson, R.N. Conner and B. Ortega. 1995. Streamside zones and breeding birds in eastern Texas. Wildl. Soc. Bull. 23: 750-755.

Donnelly, D., B. Lilly and E. Smith. 2001. The Southern Variant of the Forest Vegetation Simulator. Forest Management Service Center. Fort Collins, CO.

Donovan, T.M., P.W. Jones, E.M. Annand and F.R. Thompson III. 1997. Variation in local-scale edge effects: mechanisms and landscape context. Ecology 78: 20642075.

Fischer, R.A. and N.R. Holler. 1991. Habitat use and relative abundance of gray squirrels in southern Alabama. J. Wildl. Manage. 55: 52-59.

Franklin, J.F., D.R. Berg, D.A. Thornburgh and J.C. Tappeiner. 1997. Alternative silvicultural approaches to timber harvesting: Variable retention harvest systems. In: pp. 111-139. Kohm, K.A. and J.F. Franklin (eds.). Creating a Forestry for the 21st Century: The Science of Ecosystem Management. Island Press, Washington, DC.

Glennon, M.J. and W.F. Porter. 1999. Using satellite imagery to assess landscape-scale habitat for wild turkeys. Wildl. Soc. Bull. 27: 646-653.

Goheen, J.R., R.K. Swihart, T.M. Gehring and M.S. Miller. 2003. Forces structuring tree squirrel communities in landscapes fragmented by agriculture: Species differences in perceptions of forest connectivity and carrying capacity. Oikos 102: 95-103.

Gullison, R.E. 2003. Does forest certification conserve biodiversity? Oryx 37: 153-165.

Gustafson, E.J. and T.R. Crow. 1999. HARVEST: Linking timber harvesting strategies to landscape patterns. In: pp. 309-332. Mladenoff, D.J. and W.L. Baker (eds.). Spatial Modeling of Forest Landscape Change: Approaches and Applications. Cambridge University Press, Cambridge.

Gustafson, E.J. and L.V. Rasmussen. 2002. Assessing the spatial implications of interactions among strategic forest management options using a Windows-based harvest simulator. Comput. Electron. Agric. 33(3):179-196.

Hagan, J.M., P.S. McKinley, A.L. Meehan and S.L. Grove. 1997. Diversity and abundance of landbirds in a northeastern industrial forest. J. Wildl. Manage. 61: 718-735.

Hunter, M.L., Jr. 1990. Wildlife, Forests, and Forestry: Principles of Managing Forests for Biological Diversity. Prentice-Hall, Englewood Cliffs, New Jersey. 
Hurst, G.A. and J.G. Dickson. 1992. Eastern turkey in Southern pine-oak forests. In: pp. 265-285. Dickson, J.G. (ed.). The Wild Turkey: Biology and Management. Stackpole Books, Harrisburg, PA.

Jackson, J.A. and H.R. Oulette. 2002. Downy woodpecker (Picoides pubescens). In: Poole, A., Gill, F. (eds.), The Birds of North America. The Academy of Natural Sciences, Philadelphia, and The American Ornithologists' Union, Washington, DC. No. 613.

Keppie, D.M. and R.M. Whiting. 1994. American woodcock (Scolopax minor). In: Poole, A., Gill, F. (eds.), The Birds of North America. The Academy of Natural Sciences, Philadelphia, and The American Ornithologists' Union, Washington, DC. No. 100.

Lance, A.N. and M. Phinney. 2001. Bird responses to partial retention timber harvesting in central interior British Columbia. For. Ecol. Manage. 142: 267-280.

Lapointe, F.J. and P. Legendre. 1994. A classification of pure malt scotch whiskies. Appl. Statist. 43: 237-257.

Lindenmayer, D.B. and J.F. Franklin. 1997. Managing stand structure as part of ecologically sustainable forest management in Australian mountain ash forests. Conserv. Biol. 11: 1053-1068.

Lindenmayer, D.B. and J.F. Franklin. 2002. Conserving Forest Biodiversity-A Comprehensive Multiscaled Approach. Island Press, Washington, DC.

Lindenmayer, D.B., C.R. Margules and D.B. Botkin. 2000. Indicators of biodiversity for ecologically sustainable forest management. Conserv. Biol. 14: 941-950.

Lotter, D.W. 2003. Organic agriculture. J. Sust. Agr. 21: 59-128.

Machtans, C.S., M.A. Villard and S.J. Hannon. 1996. Use of riparian buffer strips as movement corridors by forest birds. Conserv. Biol. 10: 1366-1379.

Main, M.B., F.M. Roka and R.F. Noss. 1999. Evaluating costs of conservation. Conserv. Biol. 13: 1262-1272.

Mann, C.C. and M.L. Plummer. 1993. The high cost of biodiversity. Science 260: 1868-1871.

Mazur, K.M. and P.C. James. 2000. Barred owl (Strix varia). In: Poole, A. and F. Gill (eds.), The Birds of North America. The Academy of Natural Sciences, Philadelphia, and The American Ornithologists' Union, Washington, DC. No. 508.

McGarigal, K. and B.J. Marks. 1995. FRAGSTATS: Spatial pattern analysis program for quantifying landscape structure. USDA For. Serv. Gen. Tech. Rep. PNWGTR-351.

McIntyre, N.E. 1995. Effects of forest patch size on avian diversity. Landscape Ecol. 10: 85-99.

Meiklejohn, B.A. and J.W. Hughes. 1999. Bird communities in riparian buffer strips of industrial forests. Am. Midl. Nat. 141: 172-184.

Merrill, S.B., F.J. Cuthbert and G. Oehlert. 1998. Residual patches and their contribution to forest-bird diversity on northern Minnesota aspen clearcuts. Conserv. Biol. 12: 190-199.

Noss, R.F. 1991. Effects of edge and internal patchiness on avian habitat use in an old-growth Florida hammock. Nat. Areas J. 11: 34-47.

Nupp, T.E. and R.K. Swihart. 2000. Landscape-level correlates of small-mammal assemblages in forest fragments of farmland. J. Mammal. 81: 512-526. 
Paoletti, M.G. 1995. Biodiversity, traditional landscapes and agroecosystem management. Landscape Urban Plann. 31: 117-128.

Paoletti, M.G. 1999. Using bioindicators based on biodiversity to access landscape sustainability. Agric., Ecosyst. Environ. 74: 1-18.

Pearce, D.F., E. Putz and J.K. Vanclay. 2003. Sustainable forestry in the tropics: Panacea or folly? For. Ecol. Manage. 172: 229-247.

Pimentel, D., U. Stachow, D.A. Takacs, H.W. Brubaker, A.R. Dumas, J.J. Meaney, J.A.S. O'Neil, D.E. Onsi and D.B. Corzilius. 1992. Conserving biological diversity in agricultural/forestry systems. BioScience 42: 354-362.

Rodewald, P.G., J.H. Withgott, and K.G. Smith. 1999. Pine warbler (Dendroica pinus). In: The Birds of North America, Poole, A., Gill, F. (eds), The Academy of Natural Sciences, Philadelphia, and The American Ornithologists' Union, Washington, DC. No. 438.

Roloff, G.J. and B.J. Kernohan. 1999. Evaluating reliability of habitat suitability index models. Wildl. Soc. Bull. 27: 973-985.

Rudolph, D.C. and J.G. Dickson. 1990. Streamside zone width and amphibians and reptiles abundance. The Southwest. Nat. 35: 472-476.

Schamberger, M., A.H. Farmer and J.W. Terrell. 1982. Habitat suitability index models: Introduction. USDI Fish and Wildl. Serv. FWS/OBS-82/10.

Schamberger, M.L. and L.J. O'Neil. 1986. Concepts and constrains of habitat-model testing. In: pp. 5-10. Verner, J., M.L. Morrison and C.J. Ralph (eds.). Wildlife 2000: Modeling Habitat Relationships of Terrestrial Vertebrates. The University of Wisconsin Press, Madison.

Schroeder, R.L. 1982a. Habitat suitability index models: Pine warbler. USDI Fish Wildl. Serv. FWS/OBS-82/10.28.

Schroeder, R.L. 1982b. Habitat suitability index models: Downy woodpecker. USDI Fish Wildl. Serv. FWS/OBS-82/10.38.

Schroeder, R.L. 1985. Habitat suitability index models: Eastern wild turkey. USDI Fish Wildl. Serv. Biol. Rep. 82(10.106).

Schulte, B.J., J. Buongiorno, C.R. Lin, and K. Skog. 1998. SouthPro: A computer program for managing uneven-aged loblolly pine stands. USDA For. Serv. Gen. Tech. Rep. FPL-112.

Short, H.L. 1984. Habitat suitability index models: The Arizona guild and layers of habitat models. USDI Fish and Wildl. Serv. FWS/OBS-82/10.70.

Simberloff, D. 1998. Flagships, umbrellas, and keystones: Is single-species management passe in the landscape era? Biol. Conserv. 83: 247-257.

Skole, D. and C. Compton. 1993. Tropical deforestation and habitat fragmentation in the Amazon: Satellite data from 1978 to 1988. Science 260: 1905-1910.

Soulé, M.E. and M.A. Sanjayan. 1998. Conservation Targets: Do They Help? Science 279: 2060-2061.

Soulé, M.E. and J. Terborgh. 1999. Conserving nature at regional and continental scales-a scientific program for North America. BioScience 49: 809-817.

Thogmartin, W.E. and B.A. Schaeffer. 2000. Landscape attributes associated with mortality events of wild turkeys in Arkansas. Wildl. Soc. Bull. 28: 865-874.

Thurmond, D.P. and K.V. Miller. 1994. Small mammal communities in streamside management zones. Brimleyana 21: 125-130. 
Thurmond, D.P., K.V. Miller and T.G. Harris. 1995. Effect of streamside management zone width on avifauna communities. South. J. Appl. For. 19: 166-169.

US Fish and Wildlife Service. 1981. Standards for the development of habitat suitability index models. USDI Fish Wildl. Serv. ESM 103.

USDA Forest Service. 2000. USDA Forest Service Strategic Plan (2000 Revision). USDA Forest Service, Washington, DC.

Vesely, D.G. and W.C. McComb. 2002. Salamander abundance and amphibian species richness in riparian buffer strips in the Oregon Coast Range. Forest Science 48: 291-297.

Whitaker, D.M. and W.A. Montevecchi. 1999. Breeding bird assemblages inhabiting riparian buffer strips in Newfoundland, Canada. J. Wildl. Manage. 63: 167-179.

Wigley, T.B. and T.H. Roberts. 1997. Landscape-level effects of forest management on faunal diversity in bottomland hardwoods. For. Ecol. Manage. 90: 141-154.

Wigley, T.B., W.M. Baughman, M.E. Dorcas, J.A. Gerwin, J.W. Gibbons, DC. Guynn, R.A. Lancia, Y.A. Leiden, M.S. Mitchell and K.R. Russell. 2000. Contributions of intensively managed forests to the sustainability of wildlife communities in the South. In: Sustaining Southern Forests: The Science of Forest Assessment. Southern Forest Resource Assessment. Available from: http://www.srs.fs.fed.us/sustain/ confl

Wilcove, D.S., D. Rothstein, D. Dubow, A. Phillips and E. Losos. 1998. Quantifying threats to imperiled species in the United States. BioScience 48: 607-615.

Williamson, R.D.1983. Identification of urban habitat components which affect eastern gray squirrel abundance. Urban Ecol. 7: 345-356.

Zollner, P.A. 2000. Comparing the landscape level perceptual abilities of forest sciurids in fragmented agricultural landscapes. Landscape Ecol. 15: 523-533.

$$
\text { doi:10.1300/J091v23n01_03 }
$$

